\title{
RAZPRAVE
}

\section{VPLIV PODNEBNIH SPREMEMB NA KOLIČINE VODE IN POPLAVE MORJA V SLOVENSKI ISTRI}

\author{
AVTORJI \\ dr. Gregor Kovačič \\ Univerza na Primorskem, Fakulteta za humanistične študije, Titov trg 5, SI - 6000 Koper, Slovenija \\ gregor.kovacic@fhs.upr.si
}

dr. Nataša Kolega

Univerza na Primorskem, Fakulteta za humanistične študije, Titov trg 5, SI - 6000 Koper in Harpha sea d.o.o., Čevljarska 8, SI - 6000 Koper, Slovenija

natasa.kolega@fhs.upr.si

\section{dr. Valentina Brečko Grubar}

Univerza na Primorskem, Fakulteta za humanistične študije, Titov trg 5, SI- 6000 Koper, Slovenija valentina.brecko.grubar@fhs.upr.si

DOI: $10.3986 / G V 88102$

UDK: 551.583:551.461(497.472)

COBISS: 1.01

\section{IZVLEČEK}

\section{Vpliv podnebnih sprememb na količine vode in poplave morja v slovenski Istri}

$V$ prispevku so obravnavane pretočne razmere rek $v$ slovenski Istri in dvigovanje gladine morja. $Z$ uporabo Senovega naklona smo $v$ slovenski Istri potrdili statistično značilna trenda povečevanja skupne letne višine izhlapevanja $49 \mathrm{~mm} /$ desetletje in naraščanja povprečne letne temperature zraka $0,53{ }^{\circ} \mathrm{C} /$ desetletje. Statistično značilnega zmanjševanja skupne letne višine padavin nismo potrdili. Omenjeni dejavniki podnebnih sprememb, skupaj $z$ drugimi spremembami v okolju, vplivajo na zmanjševanje srednjih letnih pretokov rek $v$ slovenski Istri 40-80 l/s na desetletje, a trendi niso statistično značilni. Padajoči trend za reko Rižano je $z$ vidika oskrbe obalnih občin s pitno vodo zelo zaskrbljujoč. Trend zviševanja srednje gladine morja (4,5 mm/desetletje) ni statistično značilen. Analiza je pokazala, da bi bilo ob dvigu gladine morja za 1 m poplavljenih 848 zgradb in ogroženih približno 3800 prebivalcev (največ v Kopru).

\section{KLJUČNE BESEDE}

podnebne spremembe, hidrološke spremenljivke, dvigovanje gladine morja, poplave morja, pokrajinska občutljivost vodnih okolij, oskrba $z$ vodo, slovenska Istra

\section{ABSTRACT \\ Climate change impacts on water quantities and sea flooding in Slovene Istria}

The article deals with discharge characteristics of rivers in Slovene Istria and with the rising of the sea level. Using the non-parametric Sen's slope test statistically significant trends of increasing annual potential evapotranspiration ( $49 \mathrm{~mm}$ per decade) and increasing mean annual air temperature $\left(0.53^{\circ} \mathrm{C}\right.$ per decade) were determined. Statistically significant decreasing of annual precipitation was not determined. These climate change factors, together with some other environmental changes, are reflected in decreasing of mean annual discharges of the rivers in Slovene Istria with the intensity of 40-80 l/s per decade, but the trends 
are not statistically significant. Decreasing trend of the Rižana river is problematic in terms of water supply in the region. Increasing trend of maximum sea level ( $4.5 \mathrm{~mm}$ per decade) is not statistically significant. Analysis showed that a total of 848 buildings would be flooded, and a total of around 3,800 people would be at risk (the majority of whom are living in Koper) if the sea level would increase by $1 \mathrm{~m}$.

\section{KEY WORDS}

climate change, hydrological variables, sea level rising, sea flooding, intrinsic vulnerability of water environments, water supply, Slovene Istria

Uredništvo je prispevek prejelo 9. marca 2016. 


\section{Uvod}

Obalno območje je posebno zaradi stika sladkih in slanih vodnih okolij, zaradi svojstvenih, tudi neugodnih naravnogeografskih značilnosti, pa se sooča s težavami, ki jih drugod v Sloveniji ni ali so prisotne $\mathrm{v}$ manjši meri. $\mathrm{V}$ primerjavi $\mathrm{z}$ večino drugih slovenskih regij, $\mathrm{v}$ slovenski Istri ni izdatnejših vodnih virov. Pogoste so poletne hidrološke suše, ko glavni vodni vir, to je kraški izvir Rižana, ob višku turistične sezone ne zadošča potrebam po pitni vodi in je treba pretežen del pitne vode zagotoviti iz drugih vodnih virov. Od leta 1970 Rižanski vodovod del vode dobi iz vodnega vira Gradole - istrski vodovod v hrvaški Istri in od leta 1994 tudi iz vodnega vira Klariči - kraški vodovod. Iz teh virov v kritično sušnih razmerah in ob največji porabi dobi tri četrtine potrebne vode (Kryžanowsky in Žigon 2012). Hkrati je območje eno od bolj ogroženih v Sloveniji zaradi požarov v naravnem okolju (Veble in Brečko Grubar 2016), sooča pa se tudi s sušami v kmetijstvu. Upoštevaje napovedi modelov bodo naravne razmere za vodne vire in obalna območja v prihodnje še bolj neugodne. Vodni odtok v porečjih je že sedaj skromen, za reke pa je značilen dežni režim z izrazitimi nižki poleti. Letne višine padavin se zmanjšujejo (Kovačič 2016) in postajajo še bolj neenakomerno razporejene. Zaradi višjih temperatur in manj padavin v topli polovici leta se bo povečala sušna ogroženost, $v$ kmetijstvu bodo večje potrebe po namakanju, višje temperature in sušne razmere bodo prizadele gozdove in ogrožena bo varovalna vloga gozdov na izpostavljenih legah. Izhlapevanje bo zmanjšalo izdatnost vodnih virov in znižalo vodostaj v vodnem omrežju, kar bo povzročilo težave $\mathrm{z}$ vodno oskrbo in povečalo pritisk na vodne vire (Ogrin 2012). Poleg težav v oskrbi z vodo se bodo spremembe odrazile tudi v večji pokrajinski občutljivosti vodnih okolij za onesnaževanje (Brečko Grubar in Kovačič 2010). Projekcije podnebnih sprememb kažejo tudi večjo verjetnost intenzivnih padavin, ploh in neviht, kar bo povečalo ogroženost zaradi hudourniških poplav, zemeljskih plazov in usadov (Ogrin 2012). Še večja nihanja pretokov rek se bodo odrazila $\mathrm{v}$ povečani eroziji in transportu sedimentov, ki sta v porečjih $\mathrm{v}$ slovenski Istri že sicer zelo intenzivna (Zorn 2008). Višje temperature zraka in morja vplivajo na dvigovanje gladine morja, kar bo povečalo poplavno ogroženost obalnih naselij in v spodnjih delih dolin (Kolega 2009).

$\mathrm{Z}$ namenom, da bi ocenili, kako bodo spremenjene odtočne značilnosti rek in dvigovanje gladine morja vplivali na vodne razmere $\mathrm{v}$ slovenski Istri v prihodnje, $\mathrm{v}$ prispevku analiziramo dostopne podatke o padavinah, temperaturah in izhlapevanju, o značilnih pretokih rek ter o gibanju gladine morja.

\section{Metodologija}

Vir podatkov o skupnih mesečnih in letnih višinah padavin $\mathrm{v}$ obdobju 1961-2010 (50 let) na padavinskih postajah Portorož-letališče, Movraž, Podgorje pod Slavnikom in Podgrad, skupnih mesečnih in letnih višinah izhlapevanja v obdobju 1971-2010 (40 let) na meteorološki postaji Portorož-letališče ter povprečnih mesečnih in letnih temperaturah zraka v obdobju 1961-2010 (50 let) na meteorološki postaji Portorož-letališče so bili homogenizirani klimatološki nizi, dostopni na spletni strani Agencije Republike Slovenije za okolje (Pregled... 2015; slika 1). Od preučevanega območja nekoliko oddaljeno padavinsko postajo Podgrad smo v analizo vključili, ker Podgrajsko podolje z brkinskimi ponikalnicami v slepih dolinah podolja predstavlja vzhodni del hidrografskega zaledja kraškega izvira Rižana (Krivic in sodelavci 1987; Krivic, Bricelj in Zupan 1989; Janža 2010). Podatke o značilnih mesečnih in letnih pretokih vodomernih postaj Rižana-Kubed II (obdobje 1966-2013, 48 let), Badaševica-Šalara (obdobje 1994-2013, 20 let), Dragonja-Podkaštel I (obdobje 1979-2013, manjkajo podatki za leto 1997, 34 let) in Drnica-Pišine I (obdobje 1995-2013, 19 let) ter podatke o dnevnih višinah morja na mareografski postaji Koper za obdobje 1963-2013 smo pridobili na Agenciji Republike Slovenije za okolje (Podatki o karakterističnih ... 2015; Podatki o dnevnih višinah ... 2015; slika 1). Za vodomerni postaji na Badaševici in Drnici sta obdobji rednih meritev za ugotavljanje trendov sprememb, $\mathrm{v}$ primerjavi z drugima dvema postajama, relativno kratki, kar je treba upoštevati pri razlagi. Na manjših 


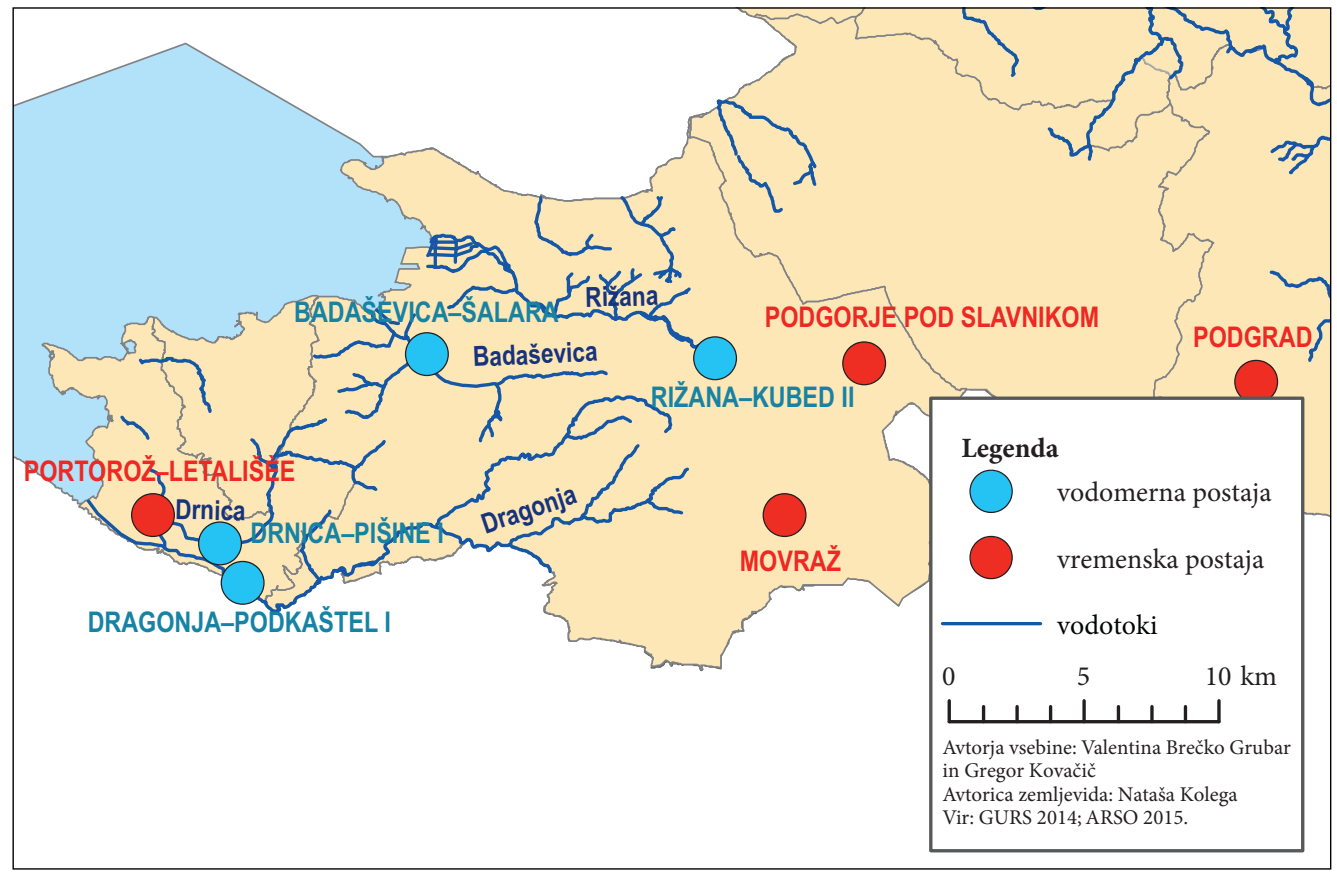

Slika 1: Vremenske postaje in glavni vodotoki z vodomernimi postajami v slovenski Istri.

vodnih tokovih, ki jih je v slovenski Istri veliko, pa hidrološke meritve ne potekajo. V članku uporabljen izraz izhlapevanje ustreza pojmu potencialna evapotranspiracija.

Med parametričnimi statističnimi pristopi za odkrivanje trenda $v$ časovnih vrstah je pogosto uporabljena ocena trenda po metodi najmanjših kvadratov, ki pa je zelo občutljiva na osamelce (angleško outliers) (Kraner Šumenjak in Šuštar 2011). Zato smo za ugotavljanje značilnih trendov spreminjanja podnebnih in hidroloških spremenljivk v raziskavi uporabili neparametrični Senov naklon (Theil-Senova cenilka) ocenjevanja naklona v linearnem modelu, ki je najpogosteje uporabljani neparametrični test za ugotavljanje linearnega časovnega trenda (Theil 1950; Sen 1968; Kraner Šumenjak in Šuštar 2011; Tilgenkamp 2011; Vannest, Parker in Gonen 2011; GraphPad Software, 2016). Senov naklon je v primerjavi z linearno regresijo bistveno bolj natančen pri asimetrično porazdeljenih in heteroskedastičnih podatkih ter daje povsem primerljive rezultate metodi najmanjših kvadratov pri normalno razporejenih podatkih (Tilgenkamp 2011). Izračunanim trendom smo pripisali $p$-vrednosti, njihovo statistično značilnost pa smo preverili pri $95 \%$ intervalu zaupanja $(\alpha=0,05)$. Analizo trenda hidroloških in podnebnih časovnih nizov smo izvedli za obdobje 1981-2010 ter rezultate primerjali tudi s trendi za daljše časovne nize.

\section{Rezultati}

\subsection{Spreminjanje padavin in izhlapevanja}

Na klimatološki postaji Portorož-letališče je v obdobju 1981-2010 v povprečju letno padlo $968 \mathrm{~mm}$, na padavinski postaji Movraž $1236 \mathrm{~mm}$, Podgorje pod Slavnikom $1427 \mathrm{~mm}$ in Podgrad $1480 \mathrm{~mm}$ padavin. Padavinski režim vseh postaj je zmerno sredozemski z viškom v jesenskih mesecih ter nižkoma 
poleti in pozimi. Največ povprečnih mesečnih padavin na postaji Portorož-letališče je bilo v septembru $(117,8 \mathrm{~mm})$, sledita oktober in november, najmanj pa $\mathrm{v}$ februarju $(53,8 \mathrm{~mm})$. Za padavinske postaje, bolj oddaljene od morja (Movraž, Podgorje in Podgrad), sta značilna izrazit prvi novembrski višek $(133,9-167,4 \mathrm{~mm})$, prvi julijski nižek $(65,8-85,7 \mathrm{~mm})$ ter večja skupna letna višina padavin. Drugi nižek na omenjenih postajah se pojavlja februarja $(78,3-94,6 \mathrm{~mm})$.

Preglednica 1: Kazalniki za skupno letno višino padavin (P), povprečno letno temperaturo zraka (T) in skupno letno višino izhlapevanja (ETP) v obdobju 1981-2010.

\begin{tabular}{|c|c|c|c|c|}
\hline $\begin{array}{l}\text { kazalnik } \\
\text { postaja }\end{array}$ & $\begin{array}{c}\text { povprečna vrednost } \\
\text { za obdobje } 1981-2010 \\
(\mathrm{P} \text { in ETP v mm; } \\
\left.\mathrm{T} \mathrm{v}^{\circ} \mathrm{C}\right)\end{array}$ & $\begin{array}{c}\text { število let } \\
\text { s podpovprečno } \\
\text { vrednostjo v primerjavi } \\
\text { z 1961-2010 }(\mathrm{P} \text { in } \mathrm{T}) \\
\text { oziroma 1971-2010 } \\
\text { (ETP) }\end{array}$ & $\begin{array}{l}\text { povprečni odklon } \\
\text { obdobja 1991-2010 } \\
\text { v primerjavi } \\
\text { z 1961-2010 (P in T) } \\
\text { in } 1971-2010 \\
\text { (ETP) }(\mathrm{v} \%)\end{array}$ & $\begin{array}{c}\text { Senov naklon } \\
\text { s p-vrednostjo } \\
\text { za obdobje } \\
\text { 1981-2010 }\end{array}$ \\
\hline $\begin{array}{l}\text { Portorož- } \\
\text { letališče (P) }\end{array}$ & 968 & 14 & $-4,80$ & $\begin{array}{c}-1,342 \\
p=0,7079\end{array}$ \\
\hline Movraž (P) & 1236 & 11 & $-1,35$ & $\begin{array}{c}3,709 \\
p=0,3265\end{array}$ \\
\hline $\begin{array}{l}\text { Podgorje pod } \\
\text { Slavnikom (P) }\end{array}$ & 1427 & 12 & $-3,72$ & $\begin{array}{c}3,119 \\
p=0,6049\end{array}$ \\
\hline Podgrad (P) & 1480 & 12 & $-4,46$ & $\begin{array}{c}-1,146 \\
p=0,7890\end{array}$ \\
\hline $\begin{array}{l}\text { Portorož- } \\
\text { letališče }(\mathrm{T})\end{array}$ & 13,2 & 17 & 4,26 & $\begin{array}{c}0,053 \\
p=0,0002\end{array}$ \\
\hline $\begin{array}{l}\text { Portorož- } \\
\text { letališče (ETP) }\end{array}$ & 998 & 16 & 4,56 & $\begin{array}{c}4,893 \\
p=0,0007\end{array}$ \\
\hline
\end{tabular}

Iz preglednice 1 je razvidno, da se leta s podpovprečnimi padavinami pogosteje pojavljajo $\mathrm{v}$ zadnjih dvajsetih letih. Če so bila v šestdesetih in sedemdesetih letih podpovprečna največ 3 ali 4 leta na desetletje, beležimo v obdobju 1991-2010 od 11 (Movraž) do 14 (Portorož-letališče) podpovprečno namočenih let $\mathrm{v}$ primerjavi $\mathrm{z}$ obdobjem 1961-2010. Povprečni negativni odkloni letnih višin padavin od povprečja 1961-2010 se za obdobje zadnjih dvajset gibljejo v razponu 1,4-4,8 \%. To kaže na postopno zmanjševanje skupne letne višine padavin na obravnavanem območju, kar dodatno potrjujejo izračunani linearni trendi letnih višin padavin za postaje Portorož-letališče, Seča in Podgrad v obdobju 1981-2010, ki pa niso statistično značilni (preglednica 1). Nasprotno od obdobja 1981-2010 so trendi za vse obravnavane postaje $\mathrm{v}$ obdobju 1961-2010 negativni in statistično značilni, $\mathrm{z}$ upadanjem letnih višin padavin od $38 \mathrm{~mm}$ (Portorož-letališče) do $63 \mathrm{~mm} /$ desetletje (Podgrad); zmanjševanje skupne višine padavin je sorazmerno $\mathrm{z}$ višino padavin na posamezni postaji in narašča $\mathrm{z}$ oddaljenostjo od obale proti notranjosti države. V obdobju 1981-2010 kažejo najbolj izrazit negativni trend padavine na postaji Portorož-letališče (13 mm/desetletje), padavinska postaja Movraž v zaledju slovenske Istre pa je tista, ki izkazuje najbolj izrazit pozitivni trend ( $37 \mathrm{~mm} /$ desetletje). Izračunani trendi se razlikujejo od prikazanih za obdobje 1951-2007 (de Luis s sodelavci 2014), so pa deloma primerljivi z $20 \%$ zmanjšanjem letne višine padavin v zahodnem delu Slovenije v obdobju 1961-2011 (Tošić s sodelavci 2016) in splošnimi negativnimi trendi letnih višin padavin v Sredozemlju in bližnjem zaledju (Toreti s sodelavci 2009). Razlike v vrednostih so lahko odraz analiz podatkov v različno dolgih časovnih nizih. 
Izhlapevanje ni merjena spremenljivka, ampak je izračunana iz podatkov o energiji planetarnega sončnega obsevanja, temperature in vlažnosti zraka ter hitrosti vetra (Trendi ... 2015). Povprečna letna temperatura zraka in višina izhlapevanja v opazovanem obdobju naraščata. Trenda obeh spremenljivk sta statistično značilna. V zadnjih dvajsetih preučevanih letih smo na klimatološki postaji Portorož-letališče, v primerjavi s povprečno temperaturo v obdobju 1961-2010, zabeležili kar 17 let $\mathrm{z}$ nadpovprečnimi vrednostmi (preglednica 1, slika 2). Povprečna letna temperatura na klimatološki postaji Portorož-letališče narašča v obdobju 1981-2010 za 0,53 (v obdobju 1961-2010 za 0,33), povprečna julijska za 0,52 (v obdobju 1961-2010 za 0,37) in povprečna januarska za 0,44 (v obdobju 1961-2010 za 0,34) ${ }^{\circ} \mathrm{C} / \mathrm{de}$ setletje. Vrednost $0,53^{\circ} \mathrm{C} /$ desetletje za postajo Portorož-letališče je nekoliko višja od vrednosti za širše obsedozemsko in sredozemsko območje (Toreti in Desiato 2008a; 2008b), je pa kar za približno 3-krat višja, kot je bila za zahodno polovico Slovenije, sicer z drugo metodo določevanja trendov, ugotovljena za obdobje 1951-2007 (de Luis s sodelavci 2014). Razlike v izračunanih vrednostih trendov so tudi tu lahko odraz analiz podatkov v različno dolgih časovnih nizih. Statistično značilen pozitiven trend povprečnih letnih temperatur v Sloveniji potrjujejo tudi druge študije (na primer Tosić s sodelavci 2016). Skladno $\mathrm{z}$ naraščanjem povprečnih letnih temperatur se povečuje tudi izhlapevanje. $\mathrm{V}$ obdobju 1981-2010 izhlapevanje narašča za $49 \mathrm{~mm} /$ desetletje (Portorož-letališče). Tudi pri izhlapevanju smo v zadnjem dvajsetletnem obdobju na postaji Portorož-letališče, v primerjavi z obdobjem 1971-2010, zabeležili 16 let $\mathrm{z}$ nadpovprečnimi vrednostmi (preglednica 1, slika 2). Po ocenah klimatologov sodi slovenska Istra med območja, kjer se je v zadnjih štiridesetih letih najbolj povečalo izhlapevanje. Odstopanja so ocenili nad 20 \% (Trendi ... 2015), kar s hkratnim zmanjševanjem skupne letne višine padavin zelo vpliva na zmanjšan vodni odtok v slovenski Istri.

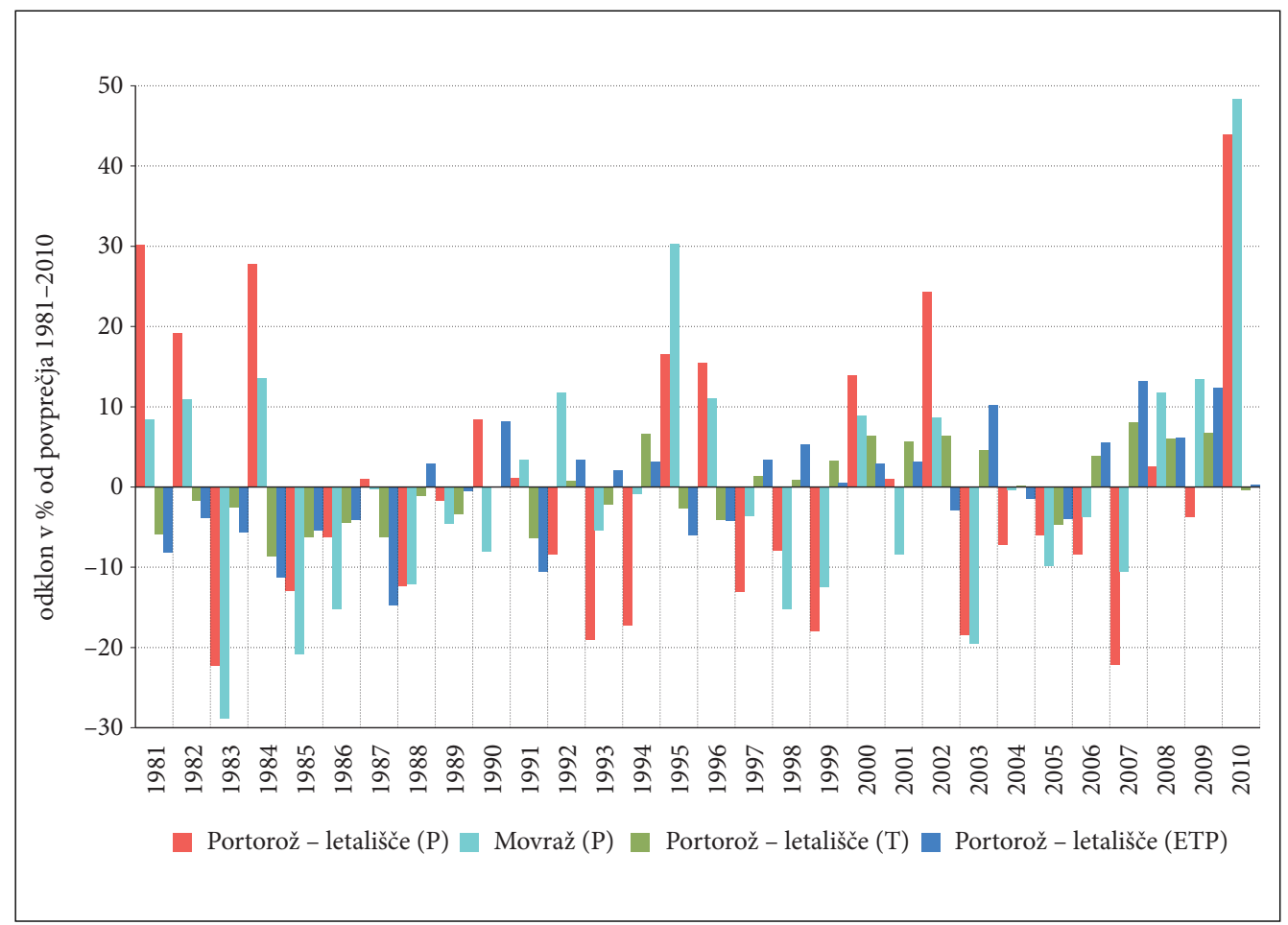

Slika 2: Odkloni letnih vrednosti ( $v \%)$ višine padavin, temperatur in višine izhlapevanja (ETP) od povprečnih vrednosti za obdobje 1981-2010 na izbranih postajah v slovenski Istri. 


\subsection{Spreminjanje odtočnih značilnosti}

Za vse vodne tokove v slovenski Istri lahko izpostavimo tri skupne značilnosti in sicer: majhno vodnatost, dežni pretočni režim z nižkom julija ali avgusta in viškom novembra ali decembra (slika 3 ) ter izrazito spreminjanje pretokov. Hudourniški značaj, če ga ocenimo iz razmerja med pretočno konico in srednjimi pretokom v obdobju, je najbolj izrazit pri Dragonji in najmanj pri Badaševici in Rižani, kar je pri slednji pogojeno z velikostjo in kraškostjo njenega vodozbirnega zaledja (preglednica 2). Največji specifični odtok v obdobju 1971-2000 je imela Rižana (18,51/s na km²), kar je posledica prevladujočega kraškega zaledja, pri ostalih treh rekah, katerih porečja obsegajo slabo prepustne flišne kamnine, pa je opazno nižji. Za Badaševico je bil 15,2 l/s na km², Dragonjo 13,2 l/s/ $/ \mathrm{km}^{2}$ in Drnico 8,4l/s na km² (Frantar 2008).

Med vsemi vodnimi tokovi je Rižana najbolj vodnata. Povprečni srednji letni pretok je bil v obdobju $1981-20103,44 \mathrm{~m}^{3} / \mathrm{s}$, povprečni najnižji $v$ juliju $0,75 \mathrm{~m}^{3} / \mathrm{s}$ in povprečni najvišji v decembru $6,3 \mathrm{~m}^{3} / \mathrm{s}$. Zabeleženi pretoki na vodomerni postaji Kubed II bi bili večji, če bi upoštevali še povprečno 240 l/s odvzete vode za vodooskrbo obalnih občin (Hočevar s sodelavci 2010). Najnižje zabeleženo stanje je bilo julija $1995\left(0,01 \mathrm{~m}^{3} / \mathrm{s}\right)$, najvišje pa septembra $2010\left(153 \mathrm{~m}^{3} / \mathrm{s}\right)$ (Podatki o karakterističnih ... 2015; preglednica 2). Ulaga (2002) je za 45-letni niz 1955-1999 skoraj na vseh opazovanih vodomernih postajah v Sloveniji ugotovila padajoč linearni trend srednjih letnih pretokov in povprečnih malih pretokov ter na približno polovici postaj tudi padajoči trend visokih konic. Za večje vodotoke je ugotovila večje negativne trende, za manj vodnate, med njimi Rižano $(-0,04)$, pa manjše. Izračunan trend je povsem primerljiv z našimi izračuni za obdobje 1966-2013, ki kažejo na statistično značilno zmanjševanje srednjega letnega pretoka Rižane za 480 l/s na desetletje, medtem ko je negativni trend za obdobje

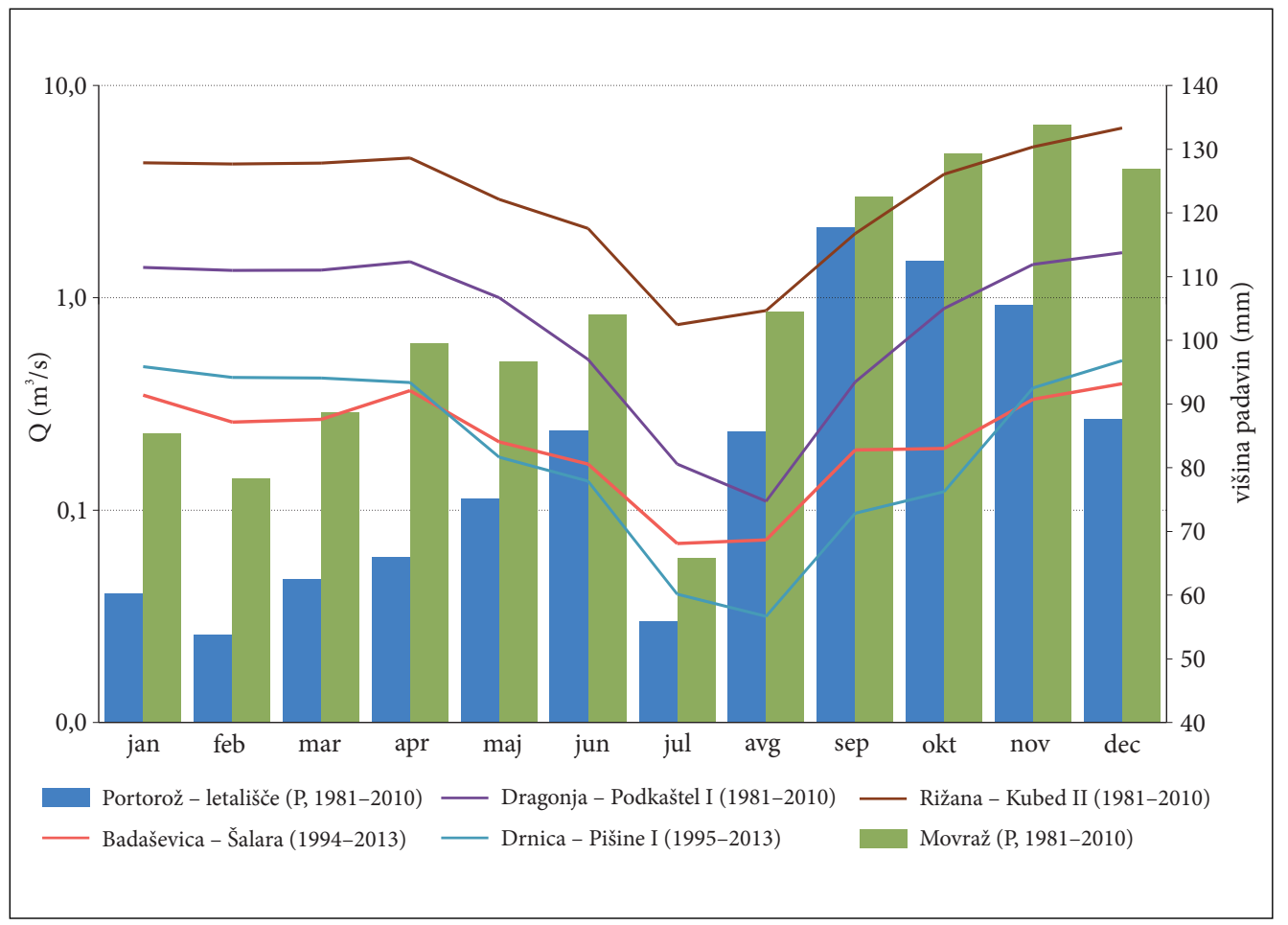

Slika 3: Hidrogram Rižane, Badaševice, Drnice in Dragonje s povprečnimi mesečnimi padavinami na postajah Portorož-letališče in Movraž. 
1981-2010 10-krat manjši (40 l/s na desetletje) in ni statistično značilen (preglednica 2). Na izjemno (40 \%) zmanjšanje srednjega letnega pretoka Rižane v obdobju 1955-2008, in sicer s $5 \mathrm{na} 3 \mathrm{~m}^{3} / \mathrm{s}$, opozarja tudi Trobec (2012), pri čemer lahko približno 7,5\% pripišemo odvzemu vode za vodooskrbo. Z vidika slednje je še bolj zaskrbljujoč negativni trend nizkih konic, ki pa se je z -31 l/s na desetletje v obdobju 1966-2013 znižal na -10 l/s na desetletje v obdobju 1981-2010. Nizke konice se praviloma pojavljajo poleti, ko je potreba po pitni vodi močno povečana. Trobec (2012) ugotavlja, da izkazuje Rižana zmanjšanje malih pretokov za kar $76 \%$. Tudi Jurko (2009) je za Rižano ugotovil statistično značilen padajoči trend za srednji letni pretok, visoko konico ter najnižji srednji dnevni pretok s trajanjem 7 in 30 dni. Na vodomerni postaji Kubed II smo v zadnjem dvajsetletnem obdobju zabeležili kar 17 let s podpovprečnim srednjim letnim pretokom v primerjavi z obdobjem 1966-2013, povprečni negativni odklon od dolgoletnega povprečja je bil 12,0\% (preglednica 2).

Preglednica 2: Kazalniki za pretoke rek v slovenski Istri v obdobju 1981-2010.

\begin{tabular}{|c|c|c|c|c|c|c|c|}
\hline $\begin{array}{l}\text { kazalnik } \\
\text { postaja }\end{array}$ & $\begin{array}{c}\mathrm{sQs} \\
\left(\mathrm{m}^{3} / \mathrm{s}\right)\end{array}$ & $\begin{array}{l}\text { nQnk } \\
\left(\mathrm{m}^{3} / \mathrm{s}\right)\end{array}$ & $\begin{array}{l}\text { vQvk } \\
\left(\mathrm{m}^{3} / \mathrm{s}\right)\end{array}$ & $\begin{array}{c}\text { razmerje } \\
\text { sQs : vQvk }\end{array}$ & $\begin{array}{l}\text { število let } \\
\text { s podpovprečno } \\
\text { vrednostjo } \\
\text { v zadnjih } \\
\text { dvajsetih letih }\end{array}$ & $\begin{array}{l}\text { povprečni odklon } \\
\text { obdobja 1991-2010 } \\
\text { v primerjavi } \\
\text { s povprečjem } \\
\text { celotnega niza ( } \mathrm{v} \%)\end{array}$ & $\begin{array}{l}\text { Senov naklon } \\
\text { za sQs } \\
\text { s p-vrednostjo } \\
\text { za obdobje } \\
\text { 1981-2010 }\end{array}$ \\
\hline $\begin{array}{l}\text { Rižana- } \\
\text { Kubed II }\end{array}$ & 3,44 & 0,010 & 153 & $1: 44$ & 17 & $-12,02$ & $\begin{array}{c}-0,004 \\
p=0,8028\end{array}$ \\
\hline $\begin{array}{l}\text { Badaševica- } \\
\text { Šalara }\end{array}$ & 0,25 & 0 & 10,3 & $1: 43$ & 1 & 1 & $\begin{array}{c}-0,008 \\
p=0,0789\end{array}$ \\
\hline $\begin{array}{l}\text { Drnica- } \\
\text { Pišine I }\end{array}$ & 0,27 & 0 & 21,4 & $1: 81$ & 1 & I & $\begin{array}{c}-0,007 \\
p=0,3449\end{array}$ \\
\hline $\begin{array}{l}\text { Dragonja- } \\
\text { Podkaštel I }\end{array}$ & 0,97 & 0 & 124 & $1: 128$ & 14 & $-5,48$ & $\begin{array}{c}-0,007 \\
p=0,3679\end{array}$ \\
\hline
\end{tabular}

Dragonja je imela v obdobju 1981-2010 na vodomerni postaji Podkaštel I srednji letni pretok (sQs) $0,97 \mathrm{~m}^{3} / \mathrm{s}$; povprečni najmanjši pretok je bil avgusta $\left(0,11 \mathrm{~m}^{3} / \mathrm{s}\right)$, povprečni najvišji pa decembra $\left(1,63 \mathrm{~m}^{3} / \mathrm{s}\right)$. Nizko stanje (nQnk) s pretokom $0 \mathrm{~m}^{3} / \mathrm{s}$ je bilo na Dragonji zabeleženo večkrat. Najvišji pretok je bil zabeležen septembra 2010 (vQvk: $124 \mathrm{~m}^{3} / \mathrm{s}$ ). Podobno kot Rižana tudi Dragonja (obdobje 1979-2013) izkazuje statistično značilen padajoči trend srednjega letnega pretoka, ki pa je manjši (1601/s na desetletje). Za obdobje 1981-2010 je negativni trend manjši (701/s na desetletje) in ni statistično značilen. Trobec (2012) navaja, da se je povprečni letni pretok Dragonje v obdobju 1979-2008 glede na enačbo linearnega trenda zmanjšal kar za $56 \%$, zmanjšanje pa je značilno tudi za male letne pretoke. Tudi po naših izračunih je v obdobju 1981-2010 statistično značilen padajoči trend nizkih pretočnih konic (10 l/s na desetletje), obratno pa velja za visoke pretočne konice, ki kažejo povečanje $\left(2,9 \mathrm{~m}^{3} / \mathrm{s}\right.$ na desetletje), vendar trend ni statistično značilen. Poleg omenjenih podnebnih dejavnikov (manjša višina padavin, višje temperature in izhlapevanje), ki vplivajo na zmanjšan vodni odtok, lahko k vzrokom za upadanje vodnatosti Dragonje prištejemo morda še vedno prisotno zaraščanje v njenem povirnem in zgornjem delu (povečevanje izhlapevanja) in odvzemanje vode za kmetijske dejavnosti v njenem spodnjem toku. Leta 1971 je bilo v porečju Dragonje le $22 \%$ gozda, leta 1994 pa že $62 \%$. Najbolj se je povečal zaradi zaraščanja travnikov in pašnikov, ki so se v tem obdobju zmanjšali za tretjino (Globevnik 1999). Na vodomerni postaji Podkaštel I smo v zadnjem dvajsetletnem obdobju opazovanja, v primerjavi z obdobjem 1979-2013, zabeležili 14 let s podpovprečnim srednjim letnim pretokom; povprečni negativni odklon od dolgoletnega povprečja je bil nekaj več kot $5 \%$ (preglednica 2). 
Badaševica in Drnica sta manj vodnati reki, obdobje merjenja pretokov pri obeh je relativno kratko, zato smo pri izračunu trenda uporabili podatke za celotni razpoložljivi obdobji meritev. Srednji letni pretok Badaševice je bil v obdobju 1994-2013 0,24 m³/s; povprečni najmanjši je bil julija $\left(0,07 \mathrm{~m}^{3} / \mathrm{s}\right)$, povprečni največji pa decembra $\left(0,39 \mathrm{~m}^{3} / \mathrm{s}\right)$. Nizko stanje s pretokom $0 \mathrm{~m}^{3} / \mathrm{s}$ je bilo na Badaševici zabeleženo večkrat. Največji zabeležen pretok pa je bil septembra $2010\left(10,3 \mathrm{~m}^{3} / \mathrm{s}\right)$. Tudi Badaševica izkazuje padajoči trend srednjega letnega pretoka $(-0,008)$, ki pa ni statistično značilen. Srednji letni pretok Drnice je bil v obdobju $1995-20130,27 \mathrm{~m}^{3} / \mathrm{s}$; povprečni najmanjši je bil avgusta $\left(0,03 \mathrm{~m}^{3} / \mathrm{s}\right)$, povprečni največji pa decembra $0,51 \mathrm{~m}^{3} / \mathrm{s}$. Nizko stanje s pretokom $0 \mathrm{~m}^{3} / \mathrm{s}$ je bilo tudi na Drnici zabeleženo večkrat. Največji pretok pa je bil septembra $2010\left(21,4 \mathrm{~m}^{3} / \mathrm{s}\right)$. Drnica ravno tako izkazuje padajoči trend srednjega letnega pretoka $(-0,007)$, ki pa, tako kot pri ostalih njenih letnih značilnih pretokih, ni statistično značilen.

\subsection{Dvigovanje gladine morja}

Planetarno segrevanje ozračja povzroča relativno hiter in intenziven dvig morske gladine, ki naj bi bil opazen že v času naše generacije. Po ocenah znanstvenikov IPCC, naj bi se morska gladina do leta 2100 dvignila tudi do $1 \mathrm{~m}$, po vsej verjetnosti pa ne manj kot $0,5 \mathrm{~m}$ (Church s sodelavci 2013); po nekaterih drugih študijah od $0,8 \mathrm{~m}$ do $2 \mathrm{~m}$ (Nuccitelli 2008). Višino morske gladine opisujemo $\mathrm{z}$ vodostaji na vodomeru mareografske postaje v Kopru. Pri tem načinu imajo vse vrednosti pozitiven predznak, saj srednji obdobni vrednosti 0 ustreza višina $215 \mathrm{~cm}$. Geodetska ničla (0) na omenjenem vodomeru ustreza vrednosti $200 \mathrm{~cm}$ oziroma $-15 \mathrm{~cm}$ glede na srednjo obdobno vrednost. Morje v slovenski Istri poplavi najnižje ležeča območja ob vodostaju 300 cm (Robič in Vrhovec 2002; Robič 2003). Povprečna dnevna amplituda gladine morja v Kopru v obdobju 1963-2013 je bila $60 \mathrm{~cm}$, razlika med najvišjo in najnižjo gladino morja pa kar $286 \mathrm{~cm}$ (Robič in Vrhovec 2002; Podatki o dnevnih ... 2015). Najvišja izmerjena gladina morja je bila leta 1969, $179 \mathrm{~cm}$ nad srednjo obdobno vrednostjo (Podatki o dnevnih ... 2015). Srednje letne višine morja na mareografski postaji Koper se zvišujejo za približno $1 \mathrm{~mm} / \mathrm{leto}$, kar je skladno s trendom spreminjana gladine Sredozemskega morja (Ličer, Jeromel in Fettich 2016). Letne najvišje gladine morja izkazujejo manjši naraščajoči trend ( $4,5 \mathrm{~mm} /$ desetletje), ki pa ni statistično značilen.

Ob najvišjih plimah, ki so pogostejše ob ščipu in mlaju v jesenskih mesecih, so se nižje ležeči deli obale že v preteklosti srečevali s poplavljanjem morja (Kolega 2005).

$\mathrm{Z}$ dvigom gladine se utegneta pogostost in obseg morskih poplav še povečati. Ob izjemno visokih plimah in velikih pretokih rek lahko obale in spodnje dele dolin prizadenejo tudi obsežne poplave.

Za lažjo predstavo, kaj bi omenjene vrednosti dviga gladine pomenile, v preglednici 3 prikazujemo višine gladine morja ob povprečni plimi, močnejši plimi in vsakoletnih ter izjemnih poplavah, ko jim dodamo vse tri napovedane vrednosti dviga $(0,5,1$ in $2 \mathrm{~m})$. Pri sedanji višini morja nižje predele slovenske Istre ogrožajo predvsem izjemne poplave.

$\mathrm{V}$ primeru dviga za $0,5 \mathrm{~m}$ sta srednja višina gladine morja in vrednost ob povprečni plimi še pod točko poplavljanja, ob visoki plimi pa ne več, saj doseže vrednost $25 \mathrm{~cm}$ nad točko poplavljanja. $V$ tem primeru bi obseg območij pod vodo lahko primerjali z območji današnjih vsakoletnih poplav $(30 \mathrm{~cm}$ nad točko poplavljanja). Ob nastopu vsakoletnih poplav $(+115 \mathrm{~cm})$ bi višina gladine morja dosegla $380 \mathrm{~cm}$, kar je le nekoliko manj od višine gladine pri današnjih izjemnih poplavah $(394 \mathrm{~cm})$. V primerjavi s sedanjim stanjem bi to pomenilo več »izjemnih « poplav letno, ko pa bi nastopile izjemne poplave, bi bila gladina kar $144 \mathrm{~cm}$ nad točko poplavljanja (Kolega 2009).

Dvig gladine za $1 \mathrm{~m}$, ki je glede na predvidevanja »srednja možnost«, bi pomenil $15 \mathrm{~cm}$ vode na najnižje ležečih delih že ob srednji višini gladine morja in le ob povprečni oseki $(-30 \mathrm{~cm})$ bi bila gladina pod točko poplavljanja. Ob povprečni plimi bi višina gladine morja dosegla vrednost $345 \mathrm{~cm}$, kar pomeni skoraj $0,5 \mathrm{~m}$ vode na najnižje ležečih delih obale, ob visoki plimi pa kar $0,75 \mathrm{~m}$. Vsakoletne poplave bi presegle razsežnost današnjih izjemnih poplav, saj bi bila gladina vode kar $36 \mathrm{~cm}$ višja $(430 \mathrm{~cm}) . \mathrm{Ob}$ izjemnih poplavah pa bi bilo na najnižje ležečih delih obale skoraj $2 \mathrm{~m}$ vode. 
Dvig za $2 \mathrm{~m}$ bi že ob srednji višini gladine morja pomenil $115 \mathrm{~cm}$ vode na najnižjih delih obale in gladina tudi ob oseki ne bi več padla pod točko poplavljanja. Ob povprečni plimi bi se višina povzpela na $145 \mathrm{~cm}$, ob visoki plimi pa na kar $175 \mathrm{~cm}$ vode na najnižjih delih obale. Ob vsakoletnih poplavah bi to pomenilo 2,3 m vode, ob izjemnih poplavah pa bi bili najnižji deli obale skoraj $3 \mathrm{~m}$ pod vodo.

Preglednica 3: Izračuni višine gladine morja po več scenarijih.

\begin{tabular}{lcccc}
\hline & sedaj & dvig za $0,5 \mathrm{~m}$ & dvig za $1 \mathrm{~m}$ & dvig za $2 \mathrm{~m}$ \\
\hline srednja višina gladine morja $(\mathrm{cm})$ & 215 & 265 & 315 & 415 \\
višina vode nad točko poplavljanja $(300 \mathrm{~cm})(\mathrm{cm})$ & 0 & 0 & 15 & 115 \\
povprečna plima $(+30 \mathrm{~cm})(\mathrm{cm})$ & 245 & 295 & 345 & 445 \\
višina vode nad točko poplavljanja $(300 \mathrm{~cm})(\mathrm{cm})$ & 0 & 0 & 45 & 145 \\
močnejša plima $(+60 \mathrm{~cm})(\mathrm{cm})$ & 275 & 325 & 375 & 475 \\
višina vode nad točko poplavljanja $(300 \mathrm{~cm})(\mathrm{cm})$ & 0 & 25 & 75 & 175 \\
vsakoletne poplave $(+115 \mathrm{~cm})(\mathrm{cm})$ & 330 & 380 & 430 & 530 \\
višina vode nad točko poplavljanja $(300 \mathrm{~cm})(\mathrm{cm})$ & 30 & 80 & 130 & 230 \\
izjemne poplave $(+179 \mathrm{~cm})(\mathrm{cm})$ & 394 & 444 & 494 & 594 \\
višina vode nad točko poplavljanja $(300 \mathrm{~cm})(\mathrm{cm})$ & 94 & 144 & 194 & 294 \\
\hline
\end{tabular}

\section{Razprava in sklepi}

Na podlagi podatkov $\mathrm{z}$ meteoroloških postaj v slovenski Istri smo za zadnja desetletja potrdili statistično značilne trende zniževanja višine padavin, naraščanja temperature zraka in povečevanja višine izhlapevanja. Spreminjanje omenjenih podnebnih elementov se odraža v zmanjšanem odtoku, kar potrjujejo statistično značilni trendi zmanjšanja značilnih pretokov rek. Z vidika vodo oskrbe je najbolj zaskrbljujoč padajoči trend srednjega pretoka Rižane (480 l/s na desetletje). Zmanjšanje vodnega odtoka je izrazitejše v topli polovici leta, ki je za slovensko Istro že sicer »kritično« obdobje za oskrbo z vodo. Zaradi višjih temperatur, daljše rastne dobe in pogostejših ter daljših sušnih obdobij naj bi se v prihodnje potrebe po vodi povečale tudi v kmetijstvu. Slednje zlasti velja za pridelavo zelenjadnic, ob daljšem pomanjkanju padavin pa tudi za poljščine in trajne nasade. Celo pridelovalci na melioriranih, nekdaj mokrotnih območjih bonifik in $\mathrm{v}$ dnu dolin, se občasno soočajo s sušo, še bolj pa so ji izpostavljeni na pobočjih in slemenih flišnega gričevja.

Na posvetovanju o podnebnih spremembah (Tveganja in priložnosti ... 2014) so ocenili, da se bo najmočnejši vpliv na vodna telesa odrazil v pogostejšem pojavljanju ter intenzivnejših sušah in poplavah ter v kakovosti vode, vključno s pitno vodo. Izpostavili so tudi poplavno ogroženost obalnih mest (slika 4). Pri ocenjevanju vplivov po regijah so najvišjo oceno, ki pomeni, da je zaradi negativnih vplivov ukrepanje nujno, pogosto namenili tudi Krasu in slovenski Istri, na primer pri pomanjkanju vode, potrebnih novih vodnih virih in zadrževalnikih, povečanju potrebne vode v kmetijstvu in suši, pogostosti požarov v naravi, pogostejših sanitarnih sečnjah, spremenjeni kakovosti vode. Trstenjakova (2013) predvideva, da se bo zaradi posrednih in neposrednih vplivov podnebnih sprememb povečala tudi ranljivost zavarovanih območij na obali.

Ker odvzemi vode iz vodotokov, katerih pretoki se opazno zmanjšujejo in so v poletnem času večinoma zelo nizki, ne bodo možni, saj bi to ogrožalo njihovo ekološko stanje, bo treba iskati druge rešitve. Ena od njih je zagotovo izbira primernih kultur, manj zahtevnih za vodo oziroma odpornejših na sušo, $\mathrm{z}$ drugačnim rastnim ciklom; druga možnost je zadrževanje vodnega odtoka in zbiranje padavin. V slovenski Istri večina padavin pade $\mathrm{v}$ jeseni in $\mathrm{z}$ zadrževanjem vodnega odtoka bi lahko zagotovili vsaj del potrebne vode za obdobje z malo padavinami, zato je že bilo predvidenih več manjših zadrževal- 
nikov, večinoma v porečju Drnice (Načrt razvoja ... 2015). Gradnja večjih zadrževalnikov predstavlja velik poseg $\mathrm{v}$ okolje in vanganelski zadrževalnik na pritoku Badaševice, ki je bil zgrajen v začetku 60 . let 20. stoletja $\mathrm{z}$ namenom zagotavljanja večje varnosti pred poplavami, je dober primer za preučitev "posledic«. V preglednici 2 prikazani podatki kažejo razlike med Badaševico in Drnico, ki jih vsaj deloma lahko pripišemo zadrževalniku. Opazno nižji so pri Badaševici visoki pretoki, tako povprečni kot najvišji, in manj izrazit je hudourniški značaj v primerjavi z Drnico. Kljub ugotovljenemu trendu zmanjševanja pretokov pa se izjemni vodni odtoki, kot so bili v septembru 2010, lahko pojavijo in povzročijo obsežne poplave. Zadrževanje vodnega odtoka z gradnjo velikih zadrževalnikov je v slovenski Istri "problematično" zaradi slabše odpornosti flišnih kamnin in intenzivnih erozijskih procesov (Zorn 2008). Primernejši so manjši zadrževalniki in druge oblike zadrževanja vode, ki lahko prav tako pomembno zmanjšajo hudourniški odtok padavin, ob pomanjkanju padavin pa bogatijo vodni pretok rek ter zagotavljajo vodo za zalivanje in oskrbo živali. Za oskrbo $\mathrm{z}$ vodo $\mathrm{v}$ sušnem obdobju je pomembno tudi vzdrževanje krajevnih vodnih virov, ki jih je v slovenski Istri po podatkih naše raziskave več kot 200. Deloma so že bili preučeni v preteklosti (Bricelj in Rejec Brancelj 1990; Zagoršek 2009), a smotrno bi jih bilo čim več popisati in primernejše za oskrbo obnoviti. Večinoma so to manj izdatni izviri ali vodnjaki s cedilno vodo, ki so pred priključitvijo naselij na Rižanski vodovod zagotavljali prebivalcem potrebno vodo, danes pa so večinoma zapuščeni in zaraščeni. Kot posledico podnebnih sprememb lahko torej v prihodnje pričakujemo še manj razpoložljive vode za oskrbo in večjo ekološko občutljivost vodnih okolij.

Pri oceni posledic dviga gladine morja smo se odločili upoštevati vrednost višine gladine morja ob dvigu za $1 \mathrm{~m}$ ob visoki plimi, torej vrednost $375 \mathrm{~cm}$ na vodomeru mareografske postaje. Slika 4 prikazuje obsežnost območja obalnega pasu, ki bi bilo poplavljeno. Obsegalo bi 1246 ha.

Območje, ki bi bilo ob visoki plimi poplavljeno, je primerljivo $\mathrm{z}$ današnjim območjem izjemnih poplav, posamezni deli slovenske obale pa bi bili različno ogroženi. Zaradi strme (klifne) obale na območju Debelega rtiča in Ankarana večjih poplavnih območij ne bi bilo. Poplavljena bi bila neposredna okolica nekdanjega mejnega prehoda Lazaret, več manjših površin na območju avtokampa v Ankaranu ter v okolici Svete Katarine. Razmeroma obsežno poplavljeno območje bi nastalo na območju Luke Koper, katere dobršni del, zlasti območje med obalo in Srminom, bi bil pod vodo. V Kopru bi na območju Bonifike nastala obsežna poplavna površina, ki bi segala vse do Olma in Šalare.

Poplavljen bi bil tudi obalni del Izole med carinskim pomolom in marino, v Strunjanu pa okolica Stjuže, soline in osrednji del Strunjana. Tako kot današnje poplave morja, bi tudi dvig gladine največ težav povzročal v Piranu, kjer je strnjena poselitev prisotna na nizki obali neposredno ob morju. Poplavljen bi bil velik del starega mestnega jedra. Na območju Bernardina in Portoroža bi bile poplavljene predvsem plaže, v Luciji pa bi se voda ob potoku Fazan lahko razširila tudi na stanovanjska območja, saj se poplavna območja zaradi zajezitve vodotokov, ki jo povzroči naraščajoča gladina morja, še dodatno razširijo. Sečoveljske soline in njihova bližja okolica bi bile poplavljene v celoti.

Število poplavljenih zgradb (hišnih naslovov) na območju slovenske Istre bi bilo 848, skupno število ogroženega prebivalstva pa približno 3800, od katerih jih največ živi v Kopru (Podatki o številu ... 2008).

Čeprav sta si današnje poplavno območje izjemnih poplav in območje, ki bi bilo poplavljeno ob dvigu gladine morja za $1 \mathrm{~m}$, po obsegu relativno podobni, pa se po svojem učinku in posledicah močno razlikujeta. Izjemne poplave, kot so bile leta 1969, bi lahko opredelili tudi kot stoletne vode in jih je zato mogoče pričakovati razmeroma redko, v nekoliko manjšem obsegu, kot na primer 1. decembra 2008, pa vsakih nekaj desetletij. Dvig gladine morja bi v nasprotju od poplav povzročil, da bi bil del obalnega pasu neprekinjeno pod morsko gladino, obseg pa bi se dodatno povečal dvakrat dnevno ob plimah. Dodatno povečanje bi bilo še do nekajkrat mesečno ob visokih plimah. Dvakrat dnevno, ter še zlasti nekajkrat mesečno ob nizkih osekah, bi bila poplavljena območja suha, vendar je raba takšnih zemljišč precej otežena oziroma nemogoča. Zato je smiselno, da bi tudi ta območja obravnavali kot trajno poplavljena. Poleg stanovanj so na tem območju prisotne še številne druge dejavnosti (pristanišče, trgovina, različne storitvene dejavnosti), na območju koprske Bonifike pa so številni objekti namenjeni 


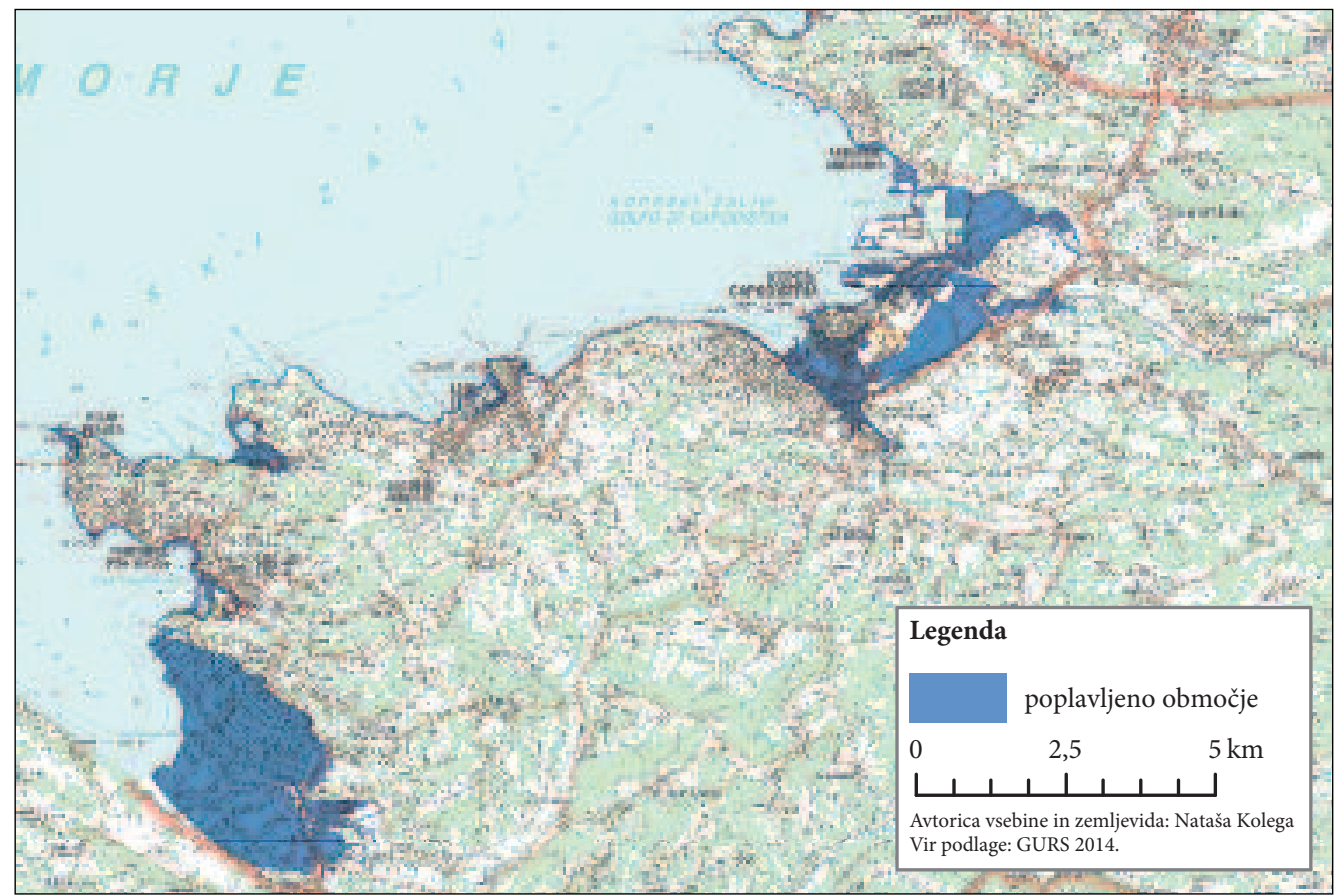

Slika 4: Prikaz območij, poplavljenih ob dvigu gladine morja za $1 \mathrm{~m}$ ob močnejši plimi $(60 \mathrm{~cm})$.

rekreaciji in šolstvu ter drugim terciarnim in kvartarnim dejavnostim. Dokončno bi »izginila« tudi zavarovana območja narave: Škocjanski zatok, Sečoveljske soline in Stjuža v Strunjanu.

Po mnenju nekaterih raziskovalcev (Nuccitelli 2008; Church s sodelavci 2013) je dvig gladine morja zaradi planetarnega segrevanja ozračja neizbežen, zato bi se bilo treba resno posvetiti pripravi scenarijev, kako omiliti posledice dviga gladine morja v obalnem pasu ter na kakšen način bi bilo mogoče zaščititi posamezna območja, zlasti nižje predele starih mestnih jeder. Nujno bi bilo izvesti podrobno analizo razlivanja morja v primeru dviga gladine na posameznih območjih slovenskega obalnega pasu in modelirati obseg združenih poplavnih območij obalnih rek in morja. V primeru močnejših morskih poplav pride do zajezitve rek na izlivih in posledično nastanka večjih sklenjenih poplavnih območij rek in morja.

\section{Viri in literatura}

Brečko Grubar, V., Kovačič, G. 2010: Pokrajinskoekološka oznaka Jadranskega povodja v Sloveniji s poudarkom na kakovosti vodnih virov. Annales, Series historia et sociologia 20-1.

Bricelj, M., Rejec Brancelj I. 1990: Oskrba z vodo v Koprskem primorju. Primorje, 15. zborovanje slovenskih geografov. Ljubljana.

Church, J. A., Clark, P. U., Cazenave, A., Gregory, J. M., Jevrejeva, S., Levermann, A., Merrifield, M. A., Milne, G. A., Nerem, R. S., Nunn, P. D., Payne, A. J., Pfeffer, W. T., Stammer, D., Unnikrishnan, A. S. 2013: Sea Level Change. Climate Change 2013. The Physical Science Basis. Contribution of Working Group I to the Fifth Assessment Report of the Intergovernmental Panel on Climate Change. Cambridge. 
de Luis, M., Čufar, K., Angel Saz, M., Alberto Longares, L., Ceglar, A., Kajfež-Bogataj, L. 2014: Trends in seasonal precipitation and temperature in Slovenia during 1951-2007. Regional Environmental Change 14. DOI: http://dx.doi.org/10.1007/s10113-012-0365-7

Frantar, P. (ur.) 2008: Vodna bilanca Slovenije 1971-2000. Ljubljana.

Globevnik, L. 1999: Analiza rabe tal, hidrološkega režima in erozijskih procesov v porečju Dragonje. Annales, Series historia naturalis 9-1.

GraphPad Software, 2016. Medmrežje: http://graphpad.com/quickcalcs/statratio1/ (10. 1. 2016).

Hočevar, Z., Knez, K., Krbavčič, S., Križman, D., Sau, S., Valentič, D., Žigon, I. 2010: Rižanski vodovod Koper - 75 let. Koper.

Janža, M. 2010: Hydrological modelling in the karst area, Rižana spring catchment, Slovenia. Environmental Earth Sciences 61-5. DOI: http://dx.doi.org/10.1007/s12665-009-0406-9

Jurko, M. 2009: Statistična analiza trendov značilnih pretokov slovenskih rek. Diplomsko delo, Fakulteta za gradbeništvo in geodezijo Univerze v Ljubljani. Ljubljana.

Kolega, N. 2005: Poplave morja na slovenski obali. Diplomsko delo, Fakulteta za humanistične študije Univerze na Primorskem. Koper.

Kolega, N. 2009: Medsebojno vplivanje kopnega in morja (Določanje značilnosti stika med kopnim in morjem s pomočjo lidarskih in sonarskih snemanj). Doktorsko delo, Fakulteta za humanistične študije Univerze na Primorskem. Koper.

Kovačič, G. 2016: Trendi pretokov rek jadranskega povodja v Sloveniji brez Posočja. Geografski vestnik 88-2. DOI: http://dx.doi.org/10.3986/GV88201

Kraner Šumenjak, T., Šuštar, V. 2011: Parametrični in neparametrični pristopi za odkrivanje trenda v časovnih vrstah. Acta agriculturae Slovenica 97-3.

Krivic, P., Bricelj, M., Trišič, N., Zupan, M. 1987: Sledenje podzemnih vod v zaledju izvira Rižane.

Acta carsologica 16.

Krivic, P., Bricelj, M., Zupan, M. 1989: Podzemne vodne zveze na področju Čičarije in osrednjega

dela Istre (Slovenija, Hrvatska, NW Jugoslavija). Acta carsologica 18.

Križanowsky, A., Žigon, I. 2012: Ureditev oskrbe prebivalstva s pitno vodo slovenske Istre in zalednega kraškega območja. 23. Mišičev vodarski dan. Maribor.

Ličer, M., Jeromel, M., Fettich, A. 2016: Prognozirano plimovanje morja 2016: Jadransko morje - Koprski zaliv. Ljubljana.

Načrt razvoja namakanja in rabe vode za namakanje v kmetijstvu do leta 2020 in program ukrepov za izvedbo načrta razvoja namakanja in rabe vode za namakanje v kmetijstvu do leta 2020. Ministrstvo za kmetijstvo, gozdarstvo in prehrano. Ljubljana, 2015. Medmrežje: http://www.mkgp.gov.si/fileadmin/ mkgp.gov.si/pageuploads/osnutki/2015/Nacrtnamakanjajuni2015.pdf (4.2.2016).

Nuccitelli, D. 2008: New studies conclude the IPCC sea level rise projections are too conservative. Planetsave. Medmrežje: http://planetsave.com/blog/2008/09/10/new-studies-conclude-the-ipccsea-level-rise-projections-are-too-conservative (30. 8. 2014).

Ogrin, D. 2012: Spreminjanje podnebja ob Tržaškem zalivu in projekcije za 21. stoletje. Geografija stika Tržaškega zaliva z zaledjem, GeograFF 12. Ljubljana.

Podatki o dnevnih višinah morja na mareografski postaji Koper 1963-2013. Agencija Republike Slovenije za okolje. Ljubljana, 2015.

Podatki o karakterističnih mesečnih in letnih pretokih Rižane na vodomerni postaji Kubed II (obdobje 1966-2013), Badaševice na vodomerni postaji Šalara (obdobje 1994-2013), Dragonje na vodomerni postaji Podkaštel I (obdobje 1979-2013) in Drnice na vodomerni postaji Pišine I (obdobje 1995-2013). Agencija Republike Slovenije za okolje. Ljubljana, 2015.

Pregled homogeniziranih klimatoloških nizov, 2015. Medmrežje: http://meteo.arso.gov.si/met/sl/climate/ diagrams/time-series/ (25.12.2015).

Podatki o številu prebivalstva na hišne naslove, območje občin Koper, Izola in Piran. Centralni register prebivalstva Ministrstva za notranje zadeve. Ljubljana, 2008. 
Robič, M. 2003: Visoke plime v letih 2002 in 2003. Ujma 17-18.

Robič, M., Vrhovec, T. 2002: Poplavljanje morske obale. Nesreče in varstvo pred njimi. Ljubljana.

Sen, P. K. 1968: Estimates of the regression coefficient based on Kendall's tau. Journal of the American Statistical Association 63.

Tilgenkamp, A. 2011: Theil-Sen estimator. Medmrežje: http://www.mathworks.com/matlabcentral/ fileexchange/34308-theil-sen-estimator (22.12.2015).

Theil, H. 1950: A rank-invariant method of linear and polynomial regression analysis. Proceedings of the Royal Netherlands Academy of Sciences 53.

Toreti, A., Desiato, F. 2008a: Temperature trend over Italy from 1961 to 2004. Theoretical and Applied Climatology 91-1. DOI: http://dx.doi.org/10.1007/s00704-006-0289-6

Toreti, A., Desiato, F. 2008b: Changes in temperature extremes over Italy in the Last 44 years. International Journal of Climatology 28-6. DOI: http://dx.doi.org/10.1002/joc.1576

Toreti, A., Fioravanti, G., Perconti, W., Desiato, F. 2009: Annual and seasonal precipitation over Italy from 1961 to 2006. International Journal of Climatology 29-13. DOI: http://dx.doi.org/10.1002/ joc. 1840

Tošić, I., Zorn, M., Ortar, J., Unkašević, M., Gavrilov, M. B., Marković, S. B. 2016: Annual and seasonal variability of precipitation and temperatures in Slovenia from 1961 to 2011. Atmospheric Research 168. DOI: http://dx.doi.org/10.1016/j.atmosres.2015.09.014

Trendi podnebnih spremenljivk in kazalcev, 2015. Medmrežje: http://www.meteo.si/met/sl/climate/ trends/ (25.12.2015).

Trobec, T. 2012: Hidrogeografske značilnosti obalnega pasu in zaledja. Geografija stika Slovenske Istre in Tržaškega zaliva. GeograFF 12. Ljubljana.

Trstenjak, K. 2013: Pričakovani vplivi podnebnih sprememb na območju Nature 2000 v obalnem pasu Slovenske Istre. Diplomsko delo, Filozofska fakulteta Univerze v Ljubljani, Ljubljana.

Tveganja in priložnosti podnebnih sprememb: Povzetek posveta o vplivanju in prilagajanju na podnebne spremembe v Sloveniji. Biotehniška fakulteta Univerze v Ljubljani. Ljubljana, 2014.

Ulaga, F. 2002: Trendi spreminjanja pretokov slovenskih rek. Dela 18.

Vannest, K. J., Parker, R. I., Gonen, O. 2011: Single case research: web based calculators for SCR analysis (version 1.0). Medmrežje: http://www.singlecaseresearch.org/calculators/theil-sen (10.1.2016).

Veble, D., Brečko Grubar, V. 2016: Pogostost in obseg požarov v naravi na Krasu in v slovenski Istri. Geografski vestnik 88-1. DOI: http://dx.doi.org/10.3986/GV88101

Zagoršek, T. 2009: Geografske značilnosti lokalnih vodnih virov v izbranih naseljih Mestne občine Koper. Diplomsko delo, Fakulteta za humanistične študije Univerze na Primorskem, Koper.

Zorn, M. 2008. Erozijski procesi v slovenski Istri. Geografija Slovenije 18. Ljubljana.

\section{Summary: Climate change impacts on water quantities and sea flooding in Slovene Istria}

(translated by Primož Kovačič)

Based on analysed data recorded at meteorological stations in Slovene Istria over the past decades, we have confirmed the statistically significant trends of increasing mean annual air temperature $\left(0.53^{\circ} \mathrm{C}\right.$ per decade) and increasing annual potential evapotranspiration ( $49 \mathrm{~mm}$ per decade). Statistically significant decreasing annual precipitation trends were not determined. Changes in the values of the abovementioned climate elements are reflected in reduced runoff in the region, which is also confirmed by the statistically significant descending trends in the characteristic discharges of the Rižana, the Dragonja, the Badaševica and the Drnica rivers.

In the study, the significant trends of change in climate and hydrological variables were determined using the non-parametric Sen's slope test (the Theil-Sen estimator), which is the most commonly used 
non-parametric test for estimating linear time trends. The statistical significance of the trends was verified at a confidence interval of $95 \%(\alpha=0.05)$. Data on total monthly and annual precipitation levels recorded in the 1961-2010 period at the precipitation measurement stations Portorož-letališče, Movraž, Podgorje pod Slavnikom and Podgrad, on total monthly and annual potential evapotranspiration levels recorded in the 1971-2010 period at the meteorological station Portorož-letališče, on average monthly and annual air temperatures recorded in the 1961-2010 period at the meteorological station Portorož-letališče, on characteristic monthly and annual discharges recorded at the gauging stations Rižana-Kubed II (the 1966-2013 period), Badaševica-Šalara (the 1994-2013 period), Dragonja-Podkaštel I (the 1979-2013 period) and Drnica-Pišine I (the 1995-2013 period), and on daily sea levels recorded in the 1963-2013 period at the Koper tide gauge station had been obtained on the Slovenian Environment Agency's website. Climatological and hydrological time series trends were calculated for the period 1981-2010. The results were also compared to calculated trends of longer time series.

The greatest concern is the descending trend in the mean discharge of the Rižana river (401/s per decade). In terms of water supply, of even greater concern are negative trends in minimum discharges, which generally appear in summer when the need for drinking water increases significantly. Higher temperatures, longer vegetation periods, and more frequent and longer dry seasons will lead to increased needs for water in agriculture, too. This mainly refers to vegetable production, but also to field crop production and orchards in longer dry periods. However, capturing water from streams whose discharges show a clear descending trend and are generally very low during the summer months will not be possible, as this will jeopardise their ecological state. In order to make drinking water supply in Slovene Istria less dependent on other water distribution systems and ensure sufficient own water resources, there have been draft plans for decades to build water retention basins. In addition, the importance of water retention basins for irrigation is also highly emphasized by agriculture experts. In Slovene Istria, most of precipitation occurs in autumn, and by collecting rainwater in retention basins at least part of the water needed in periods with scarce precipitation could be ensured. Therefore, locations for small retention basins have already been envisaged, mainly in the Drnica catchment area. Despite the identified descending trend in discharges, exceptionally high runoffs, such as the one in September 2010, can actually occur and cause extensive flooding. In Slovene Istria, restraining runoff by means of large retention basins is "problematic « due to the lack of resistance of flysch bedrock to weathering, and intensive erosion processes, and we believe that small retention basins and other means of water retention are more appropriate as they can also significantly reduce torrential runoff and, in periods of rainfall shortage, enhance the discharge of rivers and provide water for plant watering and animals. Furthermore, it is important for water supply in drought periods to maintain local water resources. According to data from our study, more than 200 of such resources are located in Slovene Istria. As a result of climate change, further reduced availability of water for water supply and increased ecological sensitivity of aquatic environments can therefore be expected in the future.

The effects of climate change with rising temperatures are also reflected in higher sea levels monitored at the Koper tide gauge station. During the highest tides, which are more frequent at a full moon and a new moon in the autumn months, the lower-lying parts of the coast have already experienced overflowing of the sea in the past, and with the rising of the sea level, the frequency and extent of sea overflowing could increase even further. Annual maximum sea levels show a moderate ascending trend (4.5 mm per decade), which, however, is not statistically significant.

When assessing the consequences of a rise in the sea level, we decided to take into account the sea level value recorded when the sea level has increased by $1 \mathrm{~m}$ during a high tide, i.e. the value of $375 \mathrm{~cm}$ indicated on the tide staff. Under such conditions, the entire flooded area would extend over 1,246 ha. The flooded area would be comparable to the present-day area of extreme flooding, with individual parts of the Slovene coast being affected differently. Due to the steep (cliffy) coast, no large flooded areas would develop in the Debeli rtič and Ankaran area. Flooding would occur in the immediate surroundings of the former border crossing point of Lazaret, with several small flooded areas developing 
in the area of the campsite in Ankaran, and around Sveta Katarina. A rather extensive flooded area would develop in the Port of Koper area, of which a considerable part, particularly the area between the coast and Srmin, would be under water. In Koper, an extensive flooded area would develop in the Bonifika area, extending as far as Olmo and Šalara. Flooding would also affect the coastal part of Izola between the customs pier and the marina, as well as the Strunjan area, specifically the area around the Stjuža lagoon, the saltpans and the central part of Strunjan.

As is the case with the overflowing of the sea occurring in the present time, a rise in the sea level would cause the most problems in Piran, where a densely populated area extends along the low-lying coast right on the seafront. A large part of the old town centre would be under water. In the Bernardin and Portorož area, mostly the beaches would be flooded, while in Lucija water along the Fazan brook could also spread over the residential areas, as flooded areas tend to expand further as a result of the blocking of streams caused by rising sea level. The Sečovlje Saltpans and their immediate surroundings would be completely under water.

In the Slovene Istria region, a total of 848 buildings (home addresses) would be flooded, and a total of around 3,800 people would be at risk, the majority of whom are living in Koper. Apart from the residents, this area is a host to a number of activities, such as port activities, trade and services, while in the Bonifika area in Koper there are many sports, recreation and educational facilities, as well as facilities used for other tertiary and quaternary activities. Moreover, rising sea level would lead to the complete »disappearance« of the Sečovlje Saltpans Landscape Park and Strunjan Landscape Park protected areas. 